\title{
AROUND LEARNING AND INDUSTRY 4.0 IN MANAGEMENT THEORY
}

\author{
Małgorzata Rozkwitalska*, Jan Slavik**
}

\begin{abstract}
Background. Management theories are products of their environment. Thus, the social, political, economic and technological forces present in a given time and locale create demand for a given theory and shape it.

Research aims. In this perspective paper the authors present how learning has evolved in management theories over the years and how challenges imposed by Industry 4.0 may impact the concepts of learning.

Methodology. The paper is based on an overview of literature and experts' work. First, the authors refer to learning in management theories from the birth of the field until the present day. Second, they portray Industry 4.0 and the current stage of implementation of its ideas. Then, they indicate the macro-environmental and workforce challenges produced by Industry 4.0. Finally, they attempt to look at the role of learning in Industry 4.0 and whether there is a need for a new theory concerning learning for the fourth industrial revolution.
\end{abstract}

Key findings. The discourse of the paper suggests that new challenges require at least a modification of the existing theories concerned with learning of individuals and organisations as well as their further improvements.

Key words: Industry 4.0, employee learning, learning organisation, knowledge management, knowledge workers, organisational learning

\section{INTRODUCTION}

Management theories are products of their environment. "Management philosophies and organizational forms change over time to meet new needs. (...) Management practices and perspectives vary in response to these social, political, and economic forces in the larger society" (Daft, 2010, pp. 33, 35).

* WSB University in Gdańsk. E-mail: mrozkwitalska@wsb.gda.pl

** Brno University of Technology. E-mail: slavik@fbm.vutbr.cz 
Learning is a vital aspect of individual and organisational functioning and "the level of education and skills of nations, companies and individuals is considered a crucial parameter of competition in the present globalised market and knowledge society" (Illeris, 2009, p. 1). For example, it affects the quality of people's interactions in an organisation, triggers an organisational change (Antonacopoulou, \& Gabriel, 2006; Carmeli, Brueller, \& Dutton, 2009; Minbaeva, Pedersen, Björkman, Fey, \& Park, 2003), and enables companies to maintain their competitive advantage (Carmeli et al., 2009). Over the years, learning has attracted substantial and growing attention of scholars, which is emphasised in theories and research on individual learning, organisational development, organisational learning, learning organisation, or knowledge management.

Industry 4.0 includes automatisation, manufacturing technologies, network-connected smart machines and data exchange. It is about the creation of smart factories, i.e. a fully integrated, automatic, and continuously optimised production environment. The goal of Industry 4.0 is an improved interaction among smart machinery modules as well as between human and machine. As it creates not only new opportunities but also challenges, undoubtedly affecting management practices and business models, it may also create a new demand for management concepts, including those related to learning.

Thus, in this perspective paper the authors attempt to combine both management theories on learning and challenges of Industry 4.0. They present how learning has evolved in management theories over the years and how challenges imposed by Industry 4.0 may impact the concepts of learning. Such an approach seems to be a missing element in the current state of knowledge about the fourth industrial revolution.

To actualise the aim of the paper, first, the authors refer to learning in management theories from the birth of the field until the present day. Second, they portray Industry 4.0 and the current stage of implementation of its ideas. Then, they indicate the macro-environmental and workforce challenges produced by Industry 4.0. Finally, they attempt to look at the role of learning in Industry 4.0 and whether there is a need for a new theory concerning learning for the fourth industrial revolution. 


\section{EVOLUTION OF LEARNING CONCEPTS IN MANAGEMENT THEORIES}

The issue of learning has been apparent in the management discipline since its very beginning; however the way it has been tackled reflects the development of the field (see Figure 1).

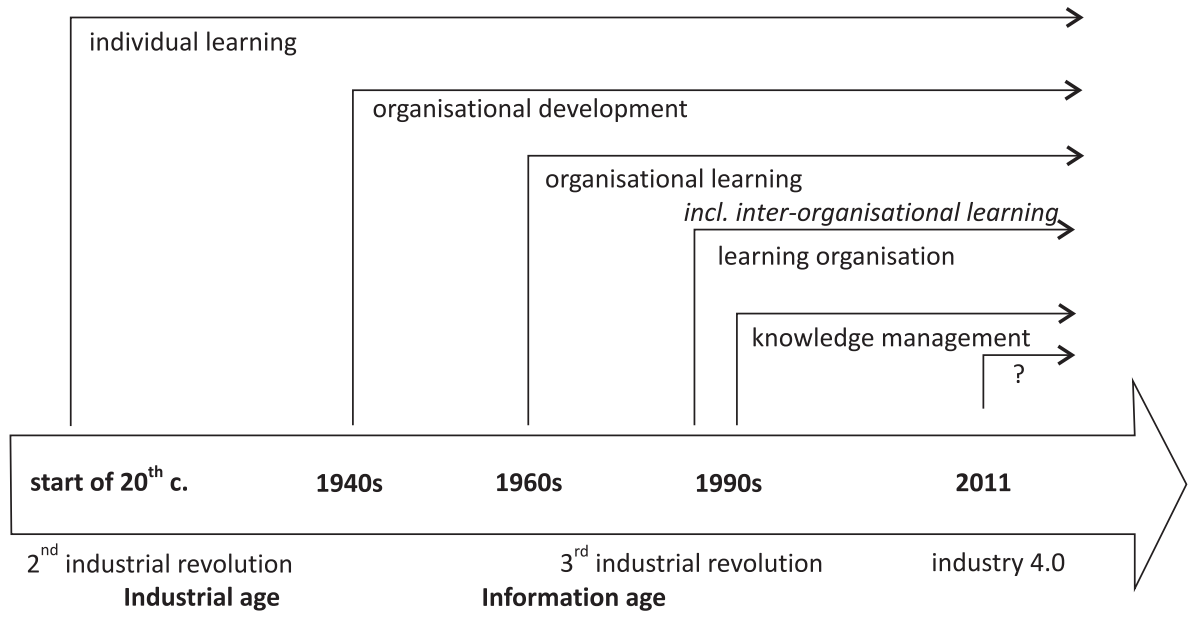

Figure 1. Learning in management concepts over the years

Source: own work.

\section{Individual learning}

An individual perspective on learning has dominated the early stage of development of the management field. Researchers have focused on employee learning and effects of this process for the organisation. The major contribution to understanding of learning has been made by psychologists, who since the late $19^{\text {th }} \mathrm{c}$. have been developing various theories of learning. Nevertheless, sociology, anthropology, philosophy, neurobiology, and other disciplines have added to the state-of-the-art knowledge about what learning is, when and how it takes place, what the outcomes of learning are, how to learn, etc. (Phillips, \& Soltis, 2009). The complexity of the learning process and its object, man, has resulted in at least three major perspectives on learning, i.e. behaviourism, cognitivism, and constructivism with their own theories on learning (Davis, Edmunds, \& Kelly-Bateman, 
2010; Wenger, 2009). To date, however, scholars have failed to propose a single comprehensive theory of learning (Phillips, \& Soltis, 2009).

Table 1. Individual learning and models of man

\begin{tabular}{|c|c|c|c|}
\hline $\begin{array}{l}\text { Rational man } \\
\text { (end of the 19th c./ } \\
\text { beginning of the } \\
\text { 20th c.) }\end{array}$ & $\begin{array}{l}\text { Social man } \\
(1930 s-1940 s)\end{array}$ & $\begin{array}{l}\text { Self-actualising } \\
\text { man }(1950 s-1960 s)\end{array}$ & $\begin{array}{l}\text { Complex man } \\
(1960 s-1980 s)\end{array}$ \\
\hline $\begin{array}{l}\text { Instrumental condi- } \\
\text { tioning of individual } \\
\text { learning to ensure } \\
\text { proper skills for a } \\
\text { simple standardised } \\
\text { task and, as a result, } \\
\text { efficiency. Workers' } \\
\text { capacities were seen } \\
\text { as natural, effortless } \\
\text { and flexible and } \\
\text { could be modified } \\
\text { by learning-in-doing } \\
\text { (Sawchuk, 2013). }\end{array}$ & $\begin{array}{l}\text { Social factors model } \\
\text { individual behaviour. } \\
\text { Informal groups } \\
\text { impact acquiring } \\
\text { certain patterns, } \\
\text { which reflects } \\
\text { learning. Yet, still } \\
\text { behaviourism shapes } \\
\text { the perception on } \\
\text { employee learning. }\end{array}$ & $\begin{array}{l}\text { An individual is an } \\
\text { active creature with } \\
\text { unlimited potential } \\
\text { aimed at self-actu- } \\
\text { alisation. Learning } \\
\text { is an inner need of } \\
\text { a person "to become } \\
\text { actualised in what } \\
\text { he is potentially" } \\
\text { (Maslow, 1954, p. } \\
\text { 46). Individuals have } \\
\text { a natural propensity } \\
\text { for learning. Feelings } \\
\text { and emotions are } \\
\text { vital in the process } \\
\text { (Braungart, \& } \\
\text { Braungart, 2003). }\end{array}$ & $\begin{array}{l}\text { Man is directed by } \\
\text { various needs and is } \\
\text { more complex than } \\
\text { just rational, social, } \\
\text { or self-actualising } \\
\text { man. His/her needs } \\
\text { change from time to } \\
\text { time. The individual } \\
\text { learning process is } \\
\text { also complex. }\end{array}$ \\
\hline
\end{tabular}

Source: own work.

As learning is a very complex matter, there is also no widely accepted definition of the concept. Traditionally, learning has been mainly perceived as the acquisition of knowledge and skills, while the contemporary concepts of learning refer it to emotional, social, and societal dimensions as well (Illeris, 2009). An example of such a holistic approach to learning was proposed by Jarvis (2009), who defined learning as "the combination of processes throughout a lifetime whereby the whole person - body (genetic, physical and biological) and mind (knowledge, skills, attitudes, values, emotions, beliefs and senses) - experiences social situations, the perceived content of which is then transformed cognitively, emotively or practically (or through any combination) and integrated into the individual person's biography resulting in a continually changing (or more experienced) person" (Jarvis, 2009, p. 25). The management discipline while deriving from learning theories in Human Resource Management (HRM) practices, so far, has not created its own theory of individual learning. Nonetheless, the five models of man in organisations, i.e. rational and social man, organisation man, self-actualising man, and complex man (Schein, 
1972; Whyte, 1956), exhibit management's perception of individual learning and its role (see Table 1).

\section{Organisational development}

Organisational development (OD) emerged as a management concept in the 1940s and was established in the 1960s (Batras, Duff, \& Smith, 2016; Lien, Hung, \& McLean, 2007) to improve organisational effectiveness or broadly understood outcomes (such as, e.g., knowledge, productivity, satisfaction, profits, etc.) and to ensure growth by planned strategy for managing a change. It primarily focuses on relationships and processes between/among individuals and groups. As such, OD is also concerned with learning and development in an organisation. OD is executed by changes in attitudes, perception, expectations, and behaviours of people. It is driven by a humanistic perspective, where man is seen as an individual aimed at growth and development (Lien et al., 2007; McLean, 2009).

Planned change management is a vital process in OD. Lewin's works on field theory, i.e. a learning theory, group dynamics, action research, and a three-step model of change, have had a profound impact on OD. In his three-step model of change learning and unlearning are of crucial importance as they facilitate the change process (Batras et al., 2016). In Lewin's view, a change is "a complex and iterative learning process" and "any attempt to predict or identify a specific outcome from planned change is very difficult because of the complexity of the forces concerned" (Burnes, 2004, p. 933, 985).

Over the years, OD has borrowed ideas from the organisational learning (OL) theory and nowadays OL is perceived as OD intervention by which managers may transform their organisations (Lien et al., 2007).

\section{Organisational learning, inter-organisational learning and learning organisation}

An organisational perspective on learning came up in the management discipline in the 1960s. It took a form of the organisational learning theory. Although OL has gained considerable attention of scholars, there is still a lack of agreement among them on what OL means (Lien et al., 2007). For instance, Argyris and Schön (1978) define OL as the process of detection and correction of errors. Easterby-Smith, Araujo 
and Burgoyne (2004) see it as a technical process aimed at effective processing, interpretation of information from inside and outside the organisation as well as responding to it. Still others perceive OL as an adaptive process of an organisation with regard to its environment (Lien et al., 2007). Notwithstanding the discrepancies in defining OL, there is consistency among researchers that: 1) OL is more than just a sum of individual learning efforts, yet organisations learn only if individuals inside them learn; 2) OL requires rethinking of patterns within an organisation as they refer to the environment; 3) OL relates to cognitive elements shared in organisational memory as well as repetitive organisational activities (Lien et al., 2007).

Mozzato and Bitencourt (2014) date back the earliest studies on inter-organisational learning (IOL) to the late 1990s and claim that IOL theory is still not sufficiently developed and poorly investigated. Nevertheless, as collaborative efforts of companies have been gaining ground in the world economy and due to their growing importance and impact on a firm's competitiveness (Mariotti, 2012), IOL has started to evoke a scientific inquiry. In view of Mozzato and Bitencourt (2014), IOL is "a dynamic process that occurs in interoganizational relations of cooperation, in different social spaces (structured and non-structured), stimulating learning situations" (Mozzato, \& Bitencourt, 2014, p. 286). Yet, to date, no unified definition of IOL has been given. Research on IOL is concerned with: 1) the creation of collective knowledge - then IOL is interpreted as a process in which organisations in network act together to create collective knowledge; 2) the creation of network rules of interaction - in such a case IOL means a process in which organisations in a network create and define their rules of interaction, namely inter-organisational practices; 3 ) knowledge acquisition and transfer - in this perspective, IOL is the collective acquisition of knowledge among organisations in a network (Mariotti, 2012).

The theory of learning organisation (LO) is mostly associated with Senge and his pivotal book from 1990 entitled The Fifth Discipline: The Art and Practice of the Learning Organization (Roper, \& Pettit, 2002), where he describes what it means to be a learning organisation. Nilsson and Eriksson (2008) posit that in contrast to OL, the concept of LO puts more emphasis on an individual who is considered to be a learning entity. LO is seen as a certain ideal kind of organisation, where different types of knowledge and learning styles are valued and enforced by organisational culture and leadership, which creates 
an encouraging learning environment to help its members to realise their full potential. Although the LO literature is rich, some academics recognise the LO theory as a borrowed toolbox or a management fad yet "pragmatic, normative and inspirational" (Roper, \& Pettit, 2002, p. 2).

\section{Knowledge management}

In the mid-1990s learning in management theory evolved and was integrated in the knowledge management (KM) field that since then has received a considerable academic attention (Sánchez Bengoa, Kaufmann, $\&$ Vrontis, 2012). Knowledge can be perceived as a product of a learning process and learning as an acquisition of knowledge (Maruta, 2014), therefore the field indirectly addresses the learning issue. KM is defined as a process where knowledge is created, distributed, and exploited to increase value from the core business competencies. It requires collection, distribution, and an efficient use of knowledge resources. Moreover, in view of proponents of the concept, $\mathrm{KM}$ enhances learning and performance in organisations (Sánchez Bengoa et al., 2012). Additionally, it can be anticipated that $\mathrm{KM}$ fosters OL and LO is a result of KM.

In the beginning of the field, researchers assumed that it is possible to document knowledge, hence they focused on how to learn, transfer and share knowledge. Gradually, they made a distinction between explicit and tacit knowledge. In the subsequent years, the studies that deal with both sources of knowledge had been expanded. With the IT development, more emphasis has been put on analysing knowledge management systems. KM has also elaborated on knowledge workers, i.e. individuals within organisations who create, distribute, or apply knowledge in their work. For these people learning is an inherent element of their work routines (Maruta, 2014).

\section{INDUSTRY 4.0 AND ITS IMPLEMENTATION}

\section{Industry 4.0 - the fourth industrial revolution}

The new trends and challenges for the present modern society come directly also from the sector of industrial companies thanks to their keen motivation and effort to implement faster and more effective modern technologies in different stages of a production process. In 
connection with the vibrant development of new modern technologies as well as a growing immense amount of their extensive implementation and interconnection of so far heterogeneous or autonomous units or areas, it has been spoken about as a digitalisation of industry, which is in the European context represented by a term of the Industry 4.0. Equivalent initiatives have appeared in the USA under terms such as the Industrial Internet Consortium or Smart Manufacturing Leadership Coalition, or other initiatives in Japan or China, as shown in Figure 2.

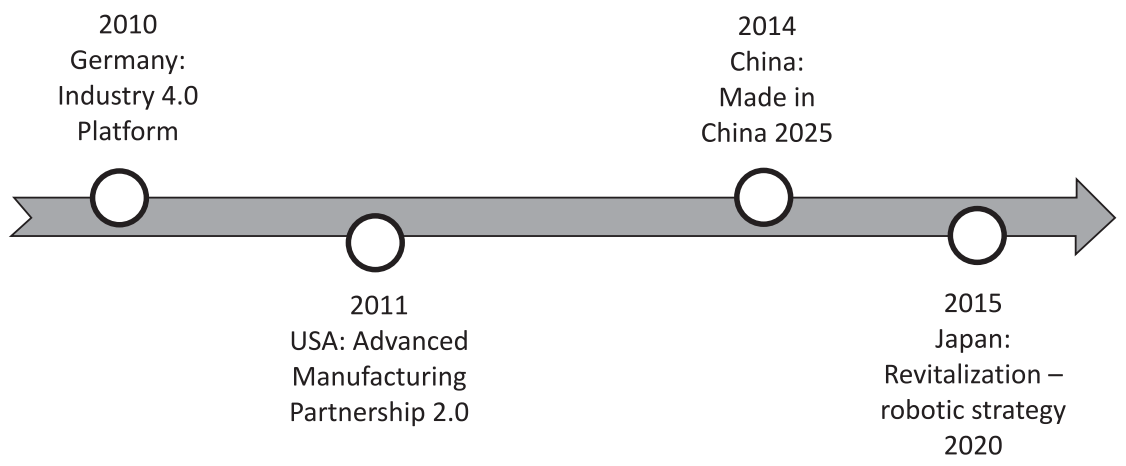

Figure 2. International initiatives launched per country

Source: adapted from Blanchet, \& Rinn, 2016.

Industry 4.0 has appeared to address certain companies' needs in economies. Table 2 compares the main motivations or rationales of these initiatives in Germany, the USA, China, and Japan.

In all these cases it is, according to Marik et al. (2015), about a new philosophy of systematic exploitation, integration and interconnection of assorted technologies for their persistent and rapid advancement. However, this new philosophy has and will have its own extensive, almost revolutionary, impact on all areas of the society. Due to its coherence with the digitalisation of industry it has been even named as the forth industrial revolution.

The term Industry 4.0 is a label created by the German government in a context of its long-term high-tech strategy 2020, which includes the forth industrial revolution - digitalisation of industry (Kagermann, Wahlster, \& Helbig, 2013). The term was established in particular in the European territory for its connection to the German economy and Germany's influence on other European countries. 
Table 2. Motivation/rationales to implement initiatives per country

\begin{tabular}{|l|c|c|c|c|}
\hline \multicolumn{1}{|c|}{ Motivations/rationales } & Germany & USA & Japan & China \\
\hline $\begin{array}{l}\text { To lower labour sensitivity, improve com- } \\
\text { petitiveness, create entry barriers }\end{array}$ & $\checkmark$ & $\checkmark$ & $\checkmark$ & $\checkmark$ \\
\hline $\begin{array}{l}\text { To produce a personalised product at mass } \\
\text { production cost }\end{array}$ & $\checkmark$ & $\checkmark$ & $\checkmark$ & $\checkmark$ \\
\hline $\begin{array}{l}\text { To develop technologies and standards, } \\
\text { create export solutions }\end{array}$ & $\checkmark$ & & $\checkmark$ & $\checkmark$ \\
\hline $\begin{array}{l}\text { To build flexible production lines, decrease } \\
\text { capital cost of geographical expansion }\end{array}$ & $\checkmark$ & & $\checkmark$ & \\
\hline $\begin{array}{l}\text { To create ecosystems for start-ups, acceler- } \\
\text { ate innovation }\end{array}$ & $\checkmark$ & & $\checkmark$ & \\
\hline To increase employee satisfaction at work & & & $\checkmark$ & \\
\hline $\begin{array}{l}\text { To secure sustainability, improve the image } \\
\text { of the industry }\end{array}$ & & & \\
\hline
\end{tabular}

Source: adapted from Blanchet, \& Rinn, 2016.

The fourth revolution comes after the three previous industrial revolutions, namely: the first one - mechanisation, use of water and steam, the second one - mass production, use of electricity and the third one - digitalisation, use of PC and microprocessors (Kagermann et al., 2013; Lasi, Fettke, Kemper, Feld, \& Hoffmann, 2014; Marik et al., 2015). It consists of automatisation, manufacturing technologies, network-connected smart machines and data exchange towards the creation of the so-called smart factories. According to Marik et al. (2015), factories will be called smart factories as soon as independent automatic operational units transform to a fully integrated, automatic, and continuously optimised production environment. "Businesses will establish global networks that incorporate their machinery, warehousing systems and production facilities in the shape of Cyber-Physical Systems (CPS). In the manufacturing environment, these CPS comprise smart machines, storage systems and production facilities capable of autonomously exchanging information, triggering actions and controlling each other independently" (Kagermann et al., 2013, p. 5).

The purpose of Industry 4.0 could be easily explained by "the introduction of the Internet of Things and Services into the manufacturing environment" (Kagermann et al., 2013, p. 5) or "to merge the virtual world with the real world, bringing IT and production closer together" (Gill, 2013, p. 1) and to perform horizontal integration, from 
a product to production. Whatsoever, Kagermann et al. (2013) predict "fundamental improvements to the industrial processes involved in manufacturing, engineering, material usage and supply chain and life cycle management" (p. 5). Within the philosophy of Industry 4.0, factories become much smarter and much more flexible, able to respond to the accelerated innovation cycle with a significant cut-down of production costs. In this view, smart machinery and human beings will exchange digital information autonomously, even start actions and control each other through the Internet protocol. Additionally, "all these new technologies and smart machinery will collect, store and give a plenty of new data through their instant connection and data exchange (the Internet of Things, the Internet of Services). It is going to be crucial for management to decide what information, at what time, to what audience and by which medium to deliver" (Slavik, 2015, p. 71).

Kagermann et al. (2013) agree, that the Industry 4.0 development is still in the beginning stage, and experts estimate that the transition is going to be more evolutional than revolutional, and it is expected, that such revolution will happen in small evolutional steps over the years. Managing director of Siemens Industry Sector, Siegfried Russwurm, is also aware of a rather evolutional character of this new industry revolution, to which he adds a very substantial and decisive factor of the human being: "The increasing penetration of IT and growing integration of all industrial technologies are taking place in evolutionary steps from today's perspective. However, looking back, the completely IT-based interaction between human, product and machine could prove to be a real industrial revolution" (Siemens Prepares the Way for Industry 4.0, 2013). The goal is an improved interaction among smart machinery modules, as well as between humans and machines.

\section{Macro-environmental challenges and Industry 4.0}

The ongoing automation and digitisation related to Industry 4.0 as well as current macro-environmental forces, i.e. economic, social, technological, environmental, political, and legal ones, create many new opportunities for business sectors as well as several challenges. They compel organisations to change their business models, impact their workplaces and, as a result, requirements concerning necessary competencies of human resources. On the one hand, Industry 4.0 
responds to these forces, on the other hand, it makes them more profound.

Concerning economic forces, even if globalisation might be in danger, as its criticism is growing and anti-liberal tendencies are spreading worldwide (Karain, 2016), it will still affect business, forcing companies to be more innovative, service-oriented, and cooperative. Customers expect a higher level of customisation and flexibility. Nowadays, markets are increasingly volatile and heterogeneous. Companies feel the pressure to cooperate with stakeholders to sustain their competitiveness. Entire value chains are becoming more and more correlated and the complexity of processes is growing. To respond to these economic forces companies need employees equipped with, e.g., intercultural skills, entrepreneurial thinking, networking abilities, and flexibility (Hecklau, Galeitzke, Flachs, \& Kohl, 2016).

The idea of Industry 4.0 has emerged to respond to significant social trends that influence business today such as eldering population and, as a result, aging workforce in many countries like Germany, Japan, and China (Shamim, Cang, Yu, \& Li, 2016) and skills' shortage (Venables, 2016). Moreover, it can be observed within the younger generation that there is a change in social values, workplaces (which are becoming more virtual), and processes (which appear more complex) (Hecklau et al., 2016). Holtgrewe (2014) points out that the fourth industrial revolution brings considerable unpredictability to workers that will increase the demand for coordination and negotiation. These trends, create, for instance, a need for employees with an ability to adapt to changing work environments, with sufficient technical skills involving use of new media, and accepting ambiguity of roles (Hecklau et al., 2016).

The technological challenges that business faces nowadays are as follows: an exponential growth of technology and data usage that lead to a necessity to deal with a huge amount of data, a growing collaboration on platforms, and a need to ensure protection against cyber-attacks. These challenges once again emphasise the importance of technical and analytical skills that enable working with data, coding and providing IT security as well as social skills for working in virtual teams (Hecklau et al., 2016). As the role of human resources in success of the fourth industrial revolution will be critical, a fundamental change in the roles which employees and managers perform in organisations is required. Venables (2016) predicts that within Industry 4.0 the 
operator will have to deal with more and more tasks, make complex decisions, "enact swift troubleshooting and oversee effective preventive maintenance strategies" (p. 29). As far as managers are concerned, they will present significant leadership skills and abilities to manage changes. With regard to Industry 4.0, Holtgrewe (2014) points out an increasing demand for ICT skills and expertise. Additionally, she indicates threats imposed by Big Data technology on certain job positions, namely devaluation or replacement of the interactive and analytical skills and knowledge of salesmen, health professionals, or bank tellers. She anticipates that their jobs may be managed by targets or recommendations basing on 'big data' without a proper understanding of the reasons behind them.

As far as environmental pressures are concerned, Hecklau et al. (2016) notice that the climate change and resource scarcity produce demands for people with "a sustainable mindset, motivation to protect the environment, creativity to develop new sustainable solutions" (p. 3). Similarly, Kagermann et al. (2013) identify the current world challenges that Industry 4.0 needs to address and solve: resource and energy efficiency, urban production, and a demographic change.

The successful transition from the third to the fourth industrial revolution imposes an obligation on governments to develop a legal framework for using Big Data to protect privacy and for work times and safety to protect workers. From the employee/manager skills' perspective it means the development of awareness of a need for IT security and compliance with the legal system.

\section{Implications on the workforce}

The fourth industrial revolution consists of automation, manufacturing technologies, interconnected smart devices, and data exchange in order to create a smart factory. Thus, the necessary elements to implement Industry 4.0 are as follows: high-tech infrastructure, information and highly skilled people (Shamim et al., 2016; Slavik, 2015).

Kagermann et al. (2013) and Lorenz, Rüßmann, Strack, Luetk, and Bolle (2015) believe that Industry 4.0 due to continuous resource productivity, efficiency gains across the entire value network and a creation of new types of interactions between people and machines will bring along important changes to the nature of work and its organisation, and an emergence of new roles and job families, in a way 
that takes a demographic change and social factors into account. They think of workers who might confront a bleaker outlook for employment, e.g. older workers or workers in routine tasks. "Older employees may be able to continue working longer if, for example, robotic assistance systems support them in physically demanding jobs or provide a stepby-step guidance for using new machines" (Lorenz et al., 2015, p. 12). Lorenz et al. give an example of cooperation between an IT developer and a smart machine operator, where the developer would need the operator's approval to reconfigure the software of a flexible production line. Such interactions between developers and operators have to be designed in a way to insure seamless handling of complex IT tasks. Lorenz et al. (2015) continue that assisted-work environments with the help of robots or cobots "will also create opportunities for people to return to the workforce in entirely new roles if they lose their jobs when their training and experience become obsolete" (Lorenz et al., 2015, p. 12). Kagermann et al. (2013) add that such "smart assistance systems release workers from having to perform routine tasks, enabling them to focus on creative, value-added activities. In view of the impending shortage of skilled workers, this will allow older workers to extend their working lives and remain productive for longer. Flexible work organization will enable workers to combine their work, private lives and continuing professional development more effectively, promoting a better work-life balance" (Kagermann et al., 2013, p. 2).

As Industry 4.0 is based on a strong increase of operational flexibility with the use of automatisation, communication nets, and digital managing systems, Slavik (2015) states that "all leaders in manufacturing agree that for this new revolution phase of the industry, there is a need for more advanced and superior robots, however the companies will need more skilled and qualified labor to operate and service the robots" (Slavik, 2015, p. 72). He predicts that there will be a need for a new approach to manage such skilled labour, more intense participation in the decision making process "as well as a focus on diversity management and life-balance of workforce" (Slavik, 2015, p. 72).

According to Lasi et al. (2014), Industry 4.0 can be defined by two development directions: application-pull and technology-push. In the technology-push direction, progress and expansion of new modern technologies (smartphones, laptops, 3D-printers, etc.) have influenced much more daily routines in private areas than in industrial jobs. The implementation of such smart equipment in the work environment, 
especially on the shop floor among the workforce, would require from the staff to acquire new abilities of how to work with special smart equipment integrated in a working process and change their approach towards their current routines and practices. As Lasi et al. (2014) continue, "there is a huge application-pull, which induces a remarkable need for changes due to changing operative framework conditions" (Lasi et al., 2014, p. 239). In particular, among the other changes, he describes that development and innovation periods need to be shortened to reduce 'time to market'. Therefore, successful manufactures have to strive for higher innovation capabilities and better coordination of overall processes and to ensure that humans in place of artificial intelligence remain responsible (Lasi et al., 2014; Lorenz et al., 2015). Both the development directions, technology-push and -pull, have implications and requirements on the abilities, knowledge, and learning potential of the workforce. Lasi et al. (2014) further explains that "the approaches and ideas in the context of Industry 4.0 are situated at the interface of the disciplines such as electrical engineering, business administrations, computer science, business and information systems, engineering and mechanical engineering as well as the participating segments" (Lasi et al., 2014, p. 240).

Lorenz et al. (2015) specifies categories of work with high job losses, such as assembly and production planning, and indicates significant job gains, particularly in IT and analytics. "The extent to which Industry 4.0 ultimately promotes higher employment will depend on how successfully companies use these technological advancements to develop new products, services, and business models" (Lorenz et al., 2015, p. 17). The higher demand resulting from the growth of existing markets and the introduction of the new products and services will create new jobs (Lorenz et al., 2015). There is a common consensus that there will be more jobs created than lost, the workforce will require significantly different skills and the role of employees will change significantly (Lorenz et al., 2015; Kagermann et al., 2013).

According to Kagermann et al. (2013), "implementation of a social-technical approach to a work organization will offer workers the opportunity to enjoy greater responsibility and enhance their personal development" (Kagermann et al., 2013, p. 6). To implement Industry 4.0 successfully, companies need to retrain their workforces, revamp their organisation models, develop strategic approaches to recruiting and workforce planning, to launch model reference projects as well 
as deploy a participative work design and lifelong learning measures (Lorenz et al., 2015; Kagermann et al., 2013).

Likewise, the analysis conducted by Hecklau et al. (2016) proves that Industry 4.0 imposes on HRM considerable challenges since it increases demand for a qualified staff equipped with broad sets of competencies. For instance, they indicate that with the spread of Industry 4.0 knowledge is becoming increasingly important, employees should have comprehensive technical skills to switch from nowadays operational tasks to more strategic ones in the future, or digitised processes require staff with coding skills. Concerning methodological competencies, they posit that the fourth industrial revolution requires employees who are: able to identify the sources of deviations and to improve processes, know how to structure and examine large amounts of data as well as able to use reliable sources for continuous learning in their changing workplace. With regard to social competencies, an employee in Industry 4.0 should, e.g., understand different cultures and divergent work habits. Due to more pressure on team work and shared work on platforms s/he is expected to be able to follow team rules. Moreover, more complex tasks and flattened hierarchies require from individuals leadership features/qualities. Finally, Hecklau et al. (2016) stress the importance of personal competencies such as flexibility, ambiguity tolerance, motivation to learn, ability to work under pressure, sustainable mindset, and compliance. They summarise that the challenge for HRM "is to qualify employees to shift their capacities to workspaces with more complex processes and ensure the retention of jobs in changing working environments" (Hecklau et al., 2016, p. 1).

\section{LEARNING IN MANAGEMENT THEORY AND INDUSTRY 4.0}

New competencies expected from employees in Industry 4.0 as well as the new form of cooperation between enterprises and their internal structure where continuous changes are becoming critically important suggest that the role of learning at individual, group, organisational, and inter-organisational levels will grow. 


\section{Individual learning theory and Industry 4.0}

Since human beings are a decisive factor in the successful implementation of Industry 4.0 and human-machine interactions will become more common, learning in interactions with machines appears to be equally important as learning in social situations. Due to digitalisation, networking and collaboration among enterprises will include more virtual rather than direct interactions. These new challenges imposed by the fourth industrial revolution may call for a new concept of man in the organization, a digitalised man who performs complex, integrated tasks, works in virtual networks with individuals from other cultures using new media and sharing information, makes complicated decisions, an active, self-directed person, open to changes and directed at life-long learning and growth. In a constantly changing environment his/her ability to learn and unlearn will become equally important.

As far as work-based learning is concerned, Industry 4.0 technologies facilitate this type of learning of shop floor workers as they may improve the presentation and delivery of work instructions, permanently update the virtual representation of physical objects, provide context-specific information and offer man-machines interfaces with novel visualisation and input options. These, in turn, positively impact delivered information, enhancing learning methodology and reducing complexity of tasks (Schuh, Gartzen, Rodenhauser, \& Marks, 2015). The fourth industrial revolution brings about technology-enabled learning which influences how the learning process should be executed and how people will learn. It calls for further development of a learning theory that takes into account interconnectedness, new media and learning of non-human appliances. Connectivism is a learning theory that may respond to these requirements, nevertheless it is questioned if it states the new paradigm or just shows directions for an additional quest for a learning theory of a new era (Kop, \& Hill, 2008). Moreover, the theory was developed before the emergence of the idea of Industry 4.0 (Siemens, 2005), it elaborates on previous social learning and constructivism theories (Kop, \& Hill, 2008) and does not sufficiently embrace human-machine interactions. 


\section{The organisational perspective on learning theory and Industry 4.0}

Concerning the organisational perspective on learning theory reflected in OD, OL, IOL, LO, and KM, it can be anticipated how challenges imposed by Industry 4.0 may impact on these concepts of learning.

First and foremost, it appears that OD with its emphasis on change management and human factors as facilitators of changes will be more valid than ever as the fourth industrial revolution is associated with permanent changes within organisations and their work environment.

With regard to OL theory, it should better integrate individual and group learning in interactions, including interactions with machines as they influence the nature of their work. The impact of machine learning on organisational memory exhibited in routines and repetitive activities need to be better exposed and explained. Another promising field of theory development is integration of the work-life balance concept into OL theory.

As Industry 4.0 brings more interconnectedness among companies, IOL will become more crucial and the theory should follow this direction of increasing collaborative efforts. Definitely, the challenges of the fourth industrial revolution stimulate a demand for IOL, i.e. the creation and acquisition of collective knowledge and new rules of network interactions embedded in organisational practices. It opens additional avenues for a scientific inquiry.

Learning in Industry 4.0 is so vital, therefore companies more than ever before should have features of $\mathrm{LO}$ and offer a supportive learning climate. New models of LO could be created by scholars as they need to include more complex interactions among organisations, humans, and machines.

Finally, knowledge in Industry 4.0 will be generated and augmented in more sophisticated interactive systems that may impact KM theory. For instance, with further advancement of IT more emphasis can be put on knowledge management systems that take into account machine learning. Management theory with respect to KM should better respond to the fact that nearly every employee, even a shop floor worker, will become a knowledge worker. Moreover, KM theory needs not only to support managers but also employees in their decisions on what information, when, to whom, and how to share. 


\section{CONCLUSIONS}

The authors were concerned with the issue of how challenges imposed by Industry 4.0 may impact the concepts of learning and whether there is a need for a new theory with that respect. They consider this approach as a missing element in the current state of the knowledge about the fourth industrial revolution and relevant since humans and learning are decisive factors for successful implementation of the idea.

The discourse of the paper suggests that new challenges require at least a modification of the existing theories of individual learning, OD, OL, IOL, LO, and KM, and their further improvements. Thus, potential avenues of the theory development were indicated in the preceding section as each theory should be valid and address new demands. As the paper is a perspective type, it reflects opinions of the authors on the relationship between management theory of learning and Industry 4.0. and, as such, is limited. Yet it may evoke an academic debate on the issue that will inspire researchers to develop an understanding of various aspects of an employee and organisational learning in Industry 4.0 .

\section{REFERENCES}

Antonacopoulou, E.P., \& Gabriel, Y. (2006). Emotion, Learning and Organizational Change. Journal of Organizational Change Management, 14(5), 435-451, https://doi.org/10.1108/EUM0000000005874 [access: 23.05.2009].

Argyris, C., \& Schön, D.A. (1978). Organizational Learning: A Theory of Action Perspective. Massachusetts: Reading, Addison-Wesley Publishing.

Batras, D., Duff, C., \& Smith, B.J. (2016). Organizational Change Theory: Implications for Health Promotion Practice. Health Promotion International, 31(1), 231-241, https://doi.org/10.1093/heapro/dau098 [access: 3.04. 2017].

Blanchet, M., \& Rinn, T. (2016). The Industrie 4.0 Transition Quantified. How the Fourth Industrial Revolution is Reshuffling the Economic, Social and Industrial Model. Munich. Retrieved from https://www.rolandberger.com/ publications/publication_pdf/roland_berger_industry_40_20160609.pdf [access: 12.12. 2017].

Braungart, M.M., \& Braungart, R.G. (2003). Applying Learning Theories to Healthcare Practice. In: Nurse as Educator: Principles of Teaching and Learning for 
Nursing Practice (pp. 43-71). Sadbury, Massachusetts: Jones and Bartlett Publishers.

Burnes, B. (2004). Kurt Lewin and the Planned Approach to Change: A Re-appraisal. Journal of Management Studies, 41(6), 977-1002, https://doi. org/10.1111/j.1467-6486.2004.00463.x [access: 2.09.2017].

Carmeli, A., Brueller, D., \& Dutton, J.E. (2009). Learning Behaviours in the Workplace: The Role of High-quality Interpersonal Relationships and Psychological Safety. Systems Research and Behavioral Science, 98 (November), 81-98, https://doi.org/10.1002/sres [access: 23.03.2016].

Daft, R.L. (2010). Management (5th ed.). Mason, Ohio: South-Western, Cengage Learning.

Davis, C., Edmunds, E., \& Kelly-Bateman, V. (2010). Connectivism. In: M. Orey (ed.), Emerging Perspectives on Learning, Teaching, and Technology (pp. 62-65). Zurich: The Global Text Project.

Easterby-Smith, M., Araujo, L., \& Burgoyne, J. (eds.) (2004). Organizational Learning and Learning Organization. Developments in Theory and Practice. London and New Delhi: Thousand Oaks, Sage Publications.

Gill, S. (2013). Industry Prepares for the Next Industrial Revolution. Control Engineering Europe. Retrieved from http://www.controlengeurope.com/ article/58949/Industry-prepares-for-the-next--industrial-revolution-.aspx [access: 14.03.2016].

Hecklau, F., Galeitzke, M., Flachs, S., \& Kohl, H. (2016). Holistic Approach for Human Resource Management in Industry 4.0. Procedia CIRP, 54, 1-6, https://doi.org/10.1016/j.procir.2016.05.102 [access: 15.04. 2017].

Holtgrewe, U. (2014). New New Technologies: The Future and the Present of Work in Information and Communication Technology. New Technology, Work and Employment, 29(1), 9-24, https://doi.org/10.1111/ntwe.12025 [access: 15.04.2017].

Illeris, K. (2009). Introduction. In: K. Illeris (ed.), Contemporary Theories of Learning. Learning Theorists... in Their Own Words (pp. 1-6). London and New York: Routledge, Taylor \& Francis Group.

Jarvis, P. (2009). Learning to be a person in society: learning to be me. In: K. Illeris (ed.), Contemporary Theories of Learning. Learning theorists ... in Their Own Words (pp. 21-34). New York: Routledge, Taylor \& Francis Group.

Kagermann, H., Wahlster, W., \& Helbig, J. (2013). Securing the Future of German Manufacturing Industry. Recommendations for Implementing the Strategic Initiative INDUSTRIE 4.0. Final Report of the Industrie 4.0 Working Group. Retrieved from http://www.acatech.de/fileadmin/user_upload/Baumstruktur_nach_Website/Acatech/root/de/Material_fuer_Sonderseiten/Industrie_4.0/ Final_report_Industrie_4.0_accessible.pdf [access: 15.04.2017]. 
Karain, J. (2016). Populists Around the World are Gaining Ground, and It's Not Looking Good for the Liberals. Retrieved from https:/qz.com/835353/ populists-around-the-world-are-gaining-ground-and-its-not-looking-goodfor-the-liberals/. [access: 25.01.2017].

Kop, R., \& Hill, A. (2008). Connectivism: Learning Theory of the Future or Vestige of the Past? The International Review of Research in Open and Distributed Learning, 9(3), 1-13.

Lasi, H., Fettke, P., Kemper, H.-G., Feld, T., \& Hoffmann, M. (2014). Industrie 4.0. Wirtschaftsomformatik, 6(4), 239-242.

Lien, B.Y.-H., Hung, R.Y., \& McLean, G.N. (2007). Organizational Learning as an Organization Development Intervention in Six High-Technology Firms in Taiwan: An Exploratory Case Study. Human Resource Development Quarterly, 18(2), 211-228, https://doi.org/10.1002/hrdq [access: 15.04.2017].

Lorenz, M., Rüßmann, M., Strack, R., Luetk, K.L., \& Bolle, M. (2015). Man and Machine in Industry 4.0. How Will Technology Transform the Industrial Workforce Through 2025? Retrieved from https://www.bcgperspectives. com/content/articles/technology-business-transformation-engineered-products-infrastructure-man-machine-industry-4/\#chapter1 [access: 1.02.2017].

Marik, V., Buncek, M., Czesana, V., Holoubek, J., Kopicova, M., Krechl, J., Valasek, M. (2015). National Initiative Industry 4.0. Praha. Retrieved from http:// www.spcr.cz/images/priloha001-2.pdf [access: 22.03.2016].

Mariotti, F. (2012). Exploring Interorganizational Learning: A Review of the Literature and Future Directions. Knowledge and Process Management, 19(4), 215-221, https://doi.org/10.1002/kpm [access: 22.03.2016].

Maruta, R. (2014). The Creation and Management of Organizational Knowledge. Knowledge-Based Systems, 67, 26-34, https://doi.org/10.1016/j.knosys.2014.06.012 [access: 22.03.2016].

Maslow, A.H. (1954). Motivation an Personality. New York: Harper \& Row Publishers.

McLean, G.N. (2009). What is Organization Development? In: Organization Development: Principles, Processes, Performance (pp. 1-32). Oakland: Berrett-Koehler Publishers, https://doi.org/DOI: 10.1080/10967491003756831 [access: 12.05.2017].

Minbaeva, D., Pedersen, T., Björkman, I., Fey, C.F., \& Park, H.J. (2003). MNC Knowledge Transfer, Subsidiary Absorptive Capacity, and HRM. Journal of International Business Studies, 34(6), 586-599, https://doi.org/10.1057/ palgrave.jibs.8400056 [access: 13.04.2017].

Mozzato, A.R., \& Bitencourt, C.C. (2014). Understanding Interorganizational Learning Based on Social Spaces and Learning Episodes. BAR - Brazilian Administration Review, 11(3), 284-301, https://doi.org/10.1590/1807-7692bar2014370 [access: 1.06.2017]. 
Nilsson, J., \& Eriksson, K. (2008). The Role of the Individual - A Key to Learning in Preparedness Organizations. Journal of Contingencies and Crisis Management, 16(3), 135-142, https://doi.org/10.1111/j.1468-5973.2008.00542.x [access: 2.04.2017].

Phillips, D.C., \& Soltis, J.F. (2009). Perspectives on Learning (5th ed.). New YorkLondon: Teaching College Columbia University.

Roper, L., \& Pettit, J. (2002). Development and the Learning Organisation: An Introduction. Development in Practice, 12(3-4), 258-271, https://doi. org/10.1080/0961450220149654 [access: 1.02.2016].

Sánchez Bengoa, D., Kaufmann, H.R., \& Vrontis, D. (2012). A New Organisational Memory for Cross-cultural Knowledge Management. Cross Cultural Management: An International Journal, 19(3), 336-351, https://doi. org/10.1108/13527601211247080 [access: 4.06.2017].

Sawchuk, P.H. (2013). Contested Learning in Walfare Work. A Study of Mind, Political Economy and the Labour Process. New York: Cambridge University Press.

Schein, E. (1972). Organizational Psychology (2nd ed.). Englewood Cliffs, NJ: Prentice-Hall.

Schuh, G., Gartzen, T., Rodenhauser, T., \& Marks, A. (2015). Promoting Work-based Learning Through INDUSTRY 4.0. Procedia CIRP, 32, 82-87, https://doi. org/10.1016/j.procir.2015.02.213 [access: 4.06.2017].

Shamim, S., Cang, S., Yu, H., \& Li, Y. (2016). Management Approaches for Industry 4.0: A Human Resource Management Perspective. In: 2016 IEEE Congress on Evolutionary Computation (CEC) (pp. 5309-5316). Vancouver, BC, https:// doi.org/10.1109/CEC.2016.7748365 [access: 4.06.2017].

Siemens, G. (2005). Connectivism: A Learning Theory for the Digital Age. International Journal of Intructional Technology \& Distance Learning, 2(1). Retrieved from http://www.itdl.org/journal/jan_05/article01.htm [access: 14.03.2015]. Siemens Prepares the Way for Industry 4.0. (2013). Hanover: Siemens. Retrieved from https://www.siemens.com/press/pool/de/pressemitteilungen/2013/industry/ I20130457e.pdf [access: 12.05.2016].

Slavik, J. (2015). Internal Corporate Communication in the Era of New Digital Technology and Industry 4.0. In: Specific research workshop 2015 (pp. 68-73). Brno: Brno University of Technology, Faculty of Business and Management. Venables, M. (2016). Are We There Yet? Works Management, 69(3), 28-30.

Wenger, E. (2009). A Social Theory of Learning. In: I. Knud (ed.), Contemporary Theories of Learning. Learning Theorists... in Their Own Words (pp. 209-218). New York: Routledge, Taylor \& Francis Group.

Whyte, W. (1956). The Organization Man. New York: Simon and Schuster. 


\section{O UCZENIU SIĘ I PRZEMYŚLE 4.0 W TEORII ZARZĄDZANIA}

\section{Abstrakt}

Tło badań. Teorie zarządzania odpowiadają na potrzeby otoczenia. Dlatego czynniki społeczne, polityczne, ekonomiczne i technologiczne obecne w danym czasie i miejscu tworzą zapotrzebowanie na daną teorię i kształtują ją.

Cele badań. W tym przeglądowym artykule autorzy pokazuja, jak problematyka uczenia się ewoluowała w teoriach zarządzania na przestrzeni lat i jak wyzwania kreowane przez przemysł 4.0 moga wpłynąć na koncepcje dotyczące uczenia się.

Metodologia. Artykuł oparty jest na przeglądzie literatury i prac ekspertów. Najpierw autorzy odwołuja się do uczenia się w teorii zarządzania od momentu narodzin dyscypliny do czasów obecnych. Następnie opisują przemysł 4.0 i obecna faze jego implementacji. W kolejnej części artykułu wskazują wyzwania w sferze makro i zasobów ludzkich kreowane przez czwartą rewolucję przemysłową. Wreszcie podejmuja próbę określenia roli uczenia się w przemyśle 4.0 oraz czy istnieje potrzeba nowej teorii dotyczącej uczenia się w czwartej rewolucji przemysłowej.

Kluczowe wnioski. Rozważania sugeruja, że nowe wyzwania indukowane przemysłem 4.0 wymagaja przynajmniej modyfikacji istniejących teorii dotyczących uczenia się jednostek i organizacji, oraz ich dalszych udoskonaleń.

Słowa kluczowe: przemysł 4.0, uczenie się pracowników, organizacja ucząca się, zarządzanie wiedza, pracownicy wiedzy, uczenie się organizacyjne 